\title{
Literary Criticism, the Works of Plotinus and their Ancient Egyptian Background
}

\section{Renata TATOMIR}

\section{Hyperion University of Bucharest}

\begin{abstract}
A simple Google search on "Plotinus" reveals no less than $1,040,000$ entries in at least 0,28 seconds, let alone the cross-searching. From these, 163,000 results are for entries like "Plotinus+literary+criticism". This fact shows how great was the influence Plotinus exerted not only on his contemporaries but also the emulation he generated among the Medieval scholars.

Plotinus's original metaphysical and symbolic approach represents a significant milestone on many levels, starting - for the sake of the topic the current volume is now addressing - with that of the literary criticism. However one could not fully explore the literary criticism of the time if one ignores the ancient Egyptian background of the philosophical system that Plotinus has created.

In this respect, the aim of the present paper is to briefly discuss some of the main Egyptian features that influenced both the literary criticism in the age of Plotinus and the mindset of his time.
\end{abstract}

Key-words: literary criticism, Enneads, Plotinus, Neoplatonism 


\section{The Works of Plotinus and their Ancient Egyptian Background}

\section{Introduction. On Ancient Literary Criticism}

Addressing the issue of the value of ancient literary criticism, Andrew Laird points out that "ancient literary criticism is something distinct from literary criticism in general ${ }^{1}$ ", hence the judgments of classical writers have little to do with contemporary production, evaluation, and theory of literature. However, writers, aestheticians, and theorists nowadays are influenced by the prescriptions and verdicts of classical authors. $^{2}$ Therefore among other influences from antiquity one may recognize the absorption of poetics and rhetoric into modern intellectual life. Besides, in the opening of his 1934 first-edition study Literary Criticism in Antiquity, Professor of English Literature J. W. H. Atkins emphasized and detailed the importance of the concept of value of ancient criticism. $^{3}$ Atkins's conception of its historical value seems to imply that what he calls the 'critical spirit' may have a cohesive and consistent identity-i.e., is not irrefutable. He affirms that ancient critical works have an 'intrinsic' value because they either contain literary principles of 'enduring value' or they announced the discussion of 'literary values'. ${ }^{4}$

When one begins to study the ancient literary criticism, one realizes that neither Greeks, nor Romans had a word or an expression corresponding to 'literature', which is a post-Enlightenment category. Hence the numerous texts which conventionally compose 'ancient literary criticism' stem from a variety of sources. These sources occupy a very wide chronological range and could be presented in different genres of discourse - spoken and written - in verse as well as in prose. Oral in origin, poetry, invective, drama, and other forms of expression are no less pertinent than the written later dialogues, essays, epistles, satires, and scholia. This is why in his 2002 The Origins of Criticism Andrew Ford emphasizes the critic's role in early Greece as a 'performer before a social group'. ${ }^{5}$ Our sources of ancient criticism derive from three major areas of expertise: poetry, rhetoric, and philosophy which represent distinct spheres of intellectual activity. ${ }^{6}$

That being said, hereinafter I chose to address the topic of literary criticism in the Neoplatonist philosophy of Plotinus. Plotinus's original metaphysical and symbolic approach represents a significant milestone on many levels, starting, for the sake of topic we are now addressing, with literary criticism. 


\section{Renata TATOMIR}

\section{Neoplatonist Philosophy}

Neoplatonist philosophy prevailed upon the third and fourth centuries C.E. 7 . To a certain extent it stemmed from the doctrines of Philo Judaeus but was systematically developed by Plotinus, the Syrian philosopher Porphyry, and Proclus. As in the case of the Second Sophistic rhetoricians, Neoplatonists held the classical authors in the highest esteem; so high that they attempted to reconcile differences between various classical authors such as Plato and Aristotle, as well as between philosophy and poetry; particularly, they attempted to reconcile Plato's theories on poetry with the poetic practice of Homer and other poets. Allegorical and symbolic modes of interpretation form their essential method, opening the way to Christian medieval conceptions of allegory and discourse. For the latters the physical world was inherently symbolic of a higher world. Macrobius, a Latin writer, passed down these Greek developments in the Middle Ages art of interpretation. ${ }^{8}$ When Stoics attempted to defend Homer and other poets from the indictment raised against them by Plato and his followers, from a literary-critical outlook the formers had at their disposal the metaphysical setting already prepared by the Neoplatonists. In this sense, the Neoplatonists reformulated Plato's metaphysical framework so as to rehabilitate and accommodate the arts. The major exponent of Neoplatonism to be examined by this paper is Plotinus and his view on literary criticism. ${ }^{9}$

\section{Plotinus (ca. 204/5-270 C.E.)}

The third-century C.E. philosopher Plotinus has been variously referred to by scholars as the greatest metaphysician of antiquity, the founder of Neoplatonism, and the thoroughest influence on Christian thought. The Neoplatonist philosophy takes from Plato the essential idea that the ultimate reality subsists in another world viewed as a transcendent and spiritual realm, from which the physical world takes its existence and meaning. In its Neoplatonic guises Plotinus' philosophy exerted a huge influence, theologically as well as mystically, extending from Augustine, Macrobius, Boethius, and medieval Christian Platonism through Italian 


\section{The Works of Plotinus and their Ancient Egyptian Background}

Renaissance humanism, the seventeenth-century Cambridge Platonists and the Romantic poets to modern thinkers and critics such as William James, Henri Bergson, A. N. Whitehead, and Harold Bloom. ${ }^{10}$

It is Plotinus' disciple, the Greek philosopher Porphyry, who recorded his master's life, and who also edited his works. According to the Greek Sophist Eunapius Plotinus was born in Lycopolis in Upper Egypt. Despite his Roman name, his cultural background seems to have been Greek and he wrote in Greek. He studied philosophy in Alexandria with the Platonist Ammonius Saccas. He was familiar with the works of the Jewish philosopher Philo and influenced not only by Plato and Aristotle but also by Stoicism, Gnosticism, and the Neo-Pythagoreans, as well as by Eastern mystery cults. ${ }^{11}$ As can be inferred, Plotinus was a man of his time, a scholar acquainted with the trendy cultural streams.

Plotinus shown interest in Persian and Indian philosophy. This tendency prompted him to join the emperor Gordian's expedition against the Persians, an endeavor that was aborted when the emperor was murdered. In 244 Plotinus established a school of philosophy in Rome. Despite this fact, however, he further unsuccessfully attempted to persuade emperor Gallienus to found a city in Campania based on the principles of Plato's Republic. After the philosopher's death, his teachings were continued by his disciples Porphyry and Iamblichus. Their last great expression as an independent philosophy was reflected in the work of Proclus (411-485). After that the echoes of Plotinus' philosophy were integrated into Christianity, particularly in the works of the Church Fathers and in Christian mysticism. ${ }^{12}$

Nonetheless, Plato's system was considerably modified, if not thoroughly transformed. This was due mainly to the activity of the three great promoters of Neoplatonism: Plotinus (204-270 C.E.), his disciple and literary executor Porphyry (233-309 C.E.), and Proclus (411-485 C.E.). ${ }^{13}$ Here are some of the Plotinian peculiarities which depart from the Plato's outlook. Plotinus thought that there were two worlds: a real world and a world of appearances. However, unlike his master, this view did not lead him to devalue the experience of art. "We must recognize", he said, that the arts "give no bare reproduction of the thing seen, but go back to the reason principle from which nature itself derives." 14 This principle was the 


\section{Renata TATOMIR}

creation of the world by the One, and a proper study of that creation could lead to a communion with the One. The One communicated an 'ideal form' to matter, giving it not just shape but beauty too. As for art it may work in a similar way. For instance, Plotinus suggests the following imagination exercise: let one imagine two stones, one left alone, the other worked by a craftsman. 'It must be seen', he points out, that the stone brought under the artist's hand ... . is beautiful not as stone but in virtue of the form or idea introduced by the art'. ${ }^{15}$ This form or idea stems from the impulse of the One to bind and control matter. Inspired by the One, the artist gathers the parts of nature and orders them into a whole, or, as Plotinus states, 'the ideal form . . . rall[ies] confusion into co-operation [and makes] one harmonious coherence, ${ }^{16}$. Hence, the art is defined by a certain type of oneness, i.e., the bringing together of different elements to make a new totality. It is this quality that makes art beautiful, or, as Plotinus remarks, 'the several parts will have beauty not in themselves, but only as working together to give a comely total' ${ }^{17}$ Beauty is art's gift to the world; it 'adds where nature lacks' ${ }^{18}$. However, one does not only find beauty in art but also in action, manners, and morality. Although one's encounter with different kinds of beauty produces slightly different effects, they will all, to a greater or lesser degree, cause the soul to strain upwards, to long to break away from the body and to mingle with the divine. The expression used to depict the feeling one gets in the presence of beauty is 'Dionysiac exultation', ${ }^{19}$ which comes from the influence of the homonymous mystery cults very trendy in Plotinus's time.

To Plotinus beauty is related to what one see, hence it has no direct relevance to how one perceives literature. Nevertheless, his comments about the topic do have a bearing on the history of criticism since they relate to artistic inspiration, the importance of form, and the twofold experience of beauty as ecstasy and moral uplift. It is a matter regarding the relation between ethics and aesthetics. Although Plotinus does not use these terms, that is of particular relevance for our topic. It goes back at least to Horace who thought that poets should 'aim either to benefit or please, or to combine the giving of pleasure with some useful precepts for life, ${ }^{20}$. The relation is always one of tension because, as Thomas Aquinas (1225- 


\section{The Works of Plotinus and their Ancient Egyptian Background}

$1274)^{21}$ remarked $^{22}$, aesthetics is a matter of contemplation while ethics is a matter of action ${ }^{23}$. One may see an example of this in different introductions to Ovid. While one commentator will look at a moral, the aim of the work is 'to persuade us to help a true friend in his hour of need', another may comment on style; but regardless of these views 'the end is for us to recognize verbal embellishments and an attractive word order' ${ }^{24}$

During this period both ethics and aesthetics derive their meaning from a metaphysical system that holds them in balance. For Plotinus, this consists of the diffuse continuity between the Creator and the created. The Creator, as the One, stands for unity while the created, as matter, stands for multiplicity. Both unity and multiplicity are simultaneously ethical and aesthetical. While Unity is form and goodness, multiplicity is formless hence evil. But once this system starts to crumble, the tension between them steps forward and one is then emphasized at the expense of the other e.g., the aesthetic movement of the late $19^{\text {th }}$ century where art was seen in terms of beauty, not morality. The fact that these terms were still current in the 1880 s and 1890 s is a proof of their longevity. In the late $20^{\text {th }}$ century, ethics and aesthetics lost their authority seen as symptoms of an order that needed change. In the 1980s and 1990s they sank to the level of unexamined assumptions. ${ }^{25}$

\subsection{Plotinus's Egyptian (and Hermetic) background}

Regarding his life, Plotinus, considered the greatest of the Neoplatonists, was born of Roman parents in the Roman province Aegyptus. ${ }^{26}$ According to Eunapius (Vita Soph. 455) and David (In Isagog. 91.23ff ), Plotinus was born in Lycopolis, Upper Egypt, (ca. 204/205 C.E.). At that time Lycopolis (modern Asyut, ancient Egyptian Zawty) was the capital of the $13^{\text {th }}$ nome of Upper Egypt, situated between

1. Akhmim (ancient Egyptian Ipu or Khen-min, Coptic Khmin, Greek Khemmis or Panopolis), the famous center of alchemy and Pythagorean philosophy, in the south ${ }^{27}$, and

2. Hermoupolis (modern el-Ashmunein, ancient Khmun, Khemmenu), the town of Hermes, Egyptian DHwtj / Thoth, the god of all knowledge, wisdom, writing, sacred rites, philosophy, and theurgy, in the 


\section{Renata TATOMIR}

north. Thoth was the undisputed master of all knowledge, the patron of scribes, doctors, magicians, and architects who built the sanctuaries of the gods, and to whom it was attributed all writings in the world. In GraecoRoman times, Hermoupolis became a famous center of pilgrimage for Egyptians, Greeks, and Romans, worshippers of the syncretic god-form Hermes Trismegistus, descendant from the Egyptian DHwtj / Thoth and the Greek Hermes. This god is sometimes regarded as a substitute of Ra (the solar Intellect, later turned into the second hypostasis of Plotinus), and equated with his heart and demiurgic logos. Lycopolis had the famous temple of the local god Upawet (Wepwawet), "the Opener of the Ways," the mystagogue of initiates and the guide through the Osirian Underworld (Duat), sometimes equated with the jackal-headed god Anubis. ${ }^{28}$

One cannot be certain about Plotinus' racial origin. He may either be a Greek, or a member of a Hellenized Egyptian family, like that of the priest Aurelius Petearbeschinis, a thoroughly Hellenized man of letters from Panopolis (Akhmim). Plotinus, who was exceedingly reticent regarding his life, is called “the Egyptian” by Proclus (Plat. Theol. I.1). At the age of twenty-eight Plotinus became interested in philosophy. He came to Alexandria and, after trying different teachers of philosophy, encountered Ammonius (ca. 175-242 C.E.), scornfully nicknamed "Saccas" by the later Christian authors, though the Neoplatonists themselves never used this disdainful label, meaning "porter." From that day Plotinus "followed Ammonius continuously, and under his guidance made such progress in philosophy that he became eager to investigate that practiced among the Persians and that perfected by the Indians” (Vita Plot. 3). ${ }^{29}$

Ammonius wrote nothing, thus very little is known about him and his teaching. John Dillon argues however that, in the person of Ammonius (who is "little more than a charismatic purveyor of Numenian Neopythagoreanism") Plotinus came into contact with the so-called "Neopythagorean underground": 30 "the great respect that he generated in his pupils for the wisdom of the East is also in line with Numenius." 31 A.H. Armstrong, who rejected the idea that Plotinus was influenced by any Hermetic teaching or by the ancient solar theologies through the 


\section{The Works of Plotinus and their Ancient Egyptian Background}

intermediary of Ammonius, states: "the chief claim to distinction of Plotinus' master, the mysterious Ammonius Saccas, was to have reconciled Plato and Aristotle, and in this he was following a well-established tradition." 32

Numenius, the second century C.E. Pythagorean and Platonic philosopher, is connected with the Syrian city of Apamea in the Orontes valley where Amelius Gentilianus of Tuscany, the chief pupil of Plotinus and admirer of Numenius, went to live just before his master Plotinus passed away. Numenius based his "perennial philosophy" not only on the teachings of Pythagoras and Plato, but also on the doctrines of the Brahmans, Jews, Magi, and Egyptians (fr. 10). He employed the technique of symbolic and allegorical exegesis, explaining the war between Atlantis and the Athenians recounted by Plato in Timaeus (23d ff), for example, as a battle between the wise followers of Athena (the noble and rational souls) and the irrational subjects of Poseidon involved with generation (Proclus, In Tim. I.76.30ff ). ${ }^{33}$

According to John Dillon, the fragments of Numenius' On the Good "give the impression much more of a Hermetic dialogue than of a Platonic one": in this treatise the main speaker reminds one of Hermes instructing his spiritual "son" Tat. ${ }^{34}$ When Plotinus was accused of appropriating the ideas of Numenius or even plagiarizing him, Amelius wrote a book in his defense called On the Difference between the Doctrines of Plotinus and Numenius. According to Porphyry the Phoenician (whose native name was Malchus), some people not only thought that Plotinus "was making a show on a basis of plagiarism from Numenius," but also considered that: "he was a big driveller and despised him because they did not understand what he meant and because he was so completely free from the staginess and windy rant of the professional speechifier: his lectures were like conversations, and he was not quick to make clear to anybody the compelling logical coherence of his discourse”. (Vita Plot. 18).

Plotinus belonged to the inner circle of Ammonius' school in Alexandria. Longinus, Erennius, and Origen the Platonist (who produced two works, On Daimons and That the King is the Only Maker) were also initiates of Ammonius. The later Neoplatonic tradition tends to emphasize the role of Ammonius in the rediscovery of true Platonism after a long 


\section{Renata TATOMIR}

period of not being properly understood. According to the Alexandrian philosopher Hierocles (whose treatise On Providence is presented in a summary by the Byzantine writer Photius), Ammonius belonged to the Golden Chain of Platonism. To describe those philosophers who rediscovered the divine philosophy, Hierocles uses the syntagma hiera genea (the golden race). He believed that Ammonius had purified true philosophy (regarded as a revelation) and restored harmony between the views of Aristotle and Plato. Thus Ammonius is introduced by the epithet “divine” (theodidaktos) (Photius, Bibl. III.112; 172a).

However, Proclus assigned this role of the "rediscoverer" to Plotinus, saying that the divine philosophy shone forth through the grace of the gods: the divine mysteries, established by the gods and guarded by the gods themselves, were in the course of time revealed to such exceptional men as Plato, who may be justly called the high priest and the chief mystagogue of those participating in the mysteries of the pure souls (Plat. Theol. I.1). Plotinus the Egyptian, he says, belongs to this "divine chorus" of true priests and hierophants, who are the exegetes of the divine mysteries of Plato and the promoters of the true interpretation of the blessed visions into which they have been initiated. Hence, the Golden Chain of philosophers (which transcends the boundaries of space and time) transmits these mysteries of "the most unadulterated and the purest light of the truth" (to gnesiotaton kai katharotaton tes aletheias phos) to future generations. ${ }^{35}$ If the role of Plotinus is somewhat crucial in this chain of transmission, as Proclus has suggested, he may then be regarded as a founder of "Neoplatonism," understood in the hieratic sense of "revival" or "return" to the revealed principles of "divine philosophy” (theia philosophia).

\subsubsection{The Ennead and the Egyptian Ennead}

Porphyry the Phoenician stayed with Plotinus only for six years, i.e., between 263-268 C.E. Plotinus started to write on the subjects that came up in the meetings of the school in the first year of Gallienus (253 C.E.) and produced twenty-one treatises until the appearance of Porphyry, who 


\section{The Works of Plotinus and their Ancient Egyptian Background}

arrived from Greece with Antonius of Rhodes. Only a few people had received copies of Plotinus' treatises at that time. According to Porphyry, "The issuing of copies was still a difficult and anxious business, not at all simple and easy; those who received them were most carefully scrutinized” (Vita Plot. 4).

No less than thirty years after the master's death in 270 C.E., these and other treatises were arranged by Porphyry into six groups of nine each. This arrangement ignored the actual chronological order in which the works were written, and so the division into fifty-four treatises is somewhat artificial. Some treatises were split up in order to make six enneads, thus giving the title Enneas to the whole collection. Number nine is prominent in ancient Egyptian theology where the gods are grouped into the Enneads.

The Ennead (psD.t/pesedjet) of Heliopolis represented the structure of the noetic cosmos constituted by four ontological levels: 1. Atum, 2. Shu and Tefnut, 3. Geb and Nut, 4. Osiris, Isis, Seth, and Nephtys. The nine gods (nTrw/neteru) of the great Ennead represent the intelligible paradigms for the world of manifestation.

However, the ancient Egyptian theological background of the psD.t was a bit different, involving some conceptual nuances. In this respect, the psD.t consisted of the main gods of a locality, not necessarily nine in number. The Ennead of Heliopolis, for instance, included the following gods:

Atum - (the creator) who brought forth

Shu - (god of air) and

Tefnut - (moisture), parents of

Geb - (earth-god) and

Nut - (the heavens) who gave birth to

Osiris,

Isis,

Seth,

Nephthys 


\section{Renata TATOMIR}

The Memphite Ennead was made up of the organs of the creator god Ptah, while Ra-Atum created an Ennead of his own body parts. The Abydos Ennead comprised seven or eleven gods, while the Theban Ennead headed by Monthu counted no less than fifteen deities. In a temple inscription at Heliopolis King Senusret I lists his offerings to a number of gods, among them the Ennead of Khereha: "(For) the Nine Gods of Khereha: a copper bowl." 36 Some enneads were of lesser importance than others, apparently depending on their composition. For instance, in his sunhymn king Horemheb wrote:

The great ennead worship thee

The lesser ennead exult to thee

They praise thee in they beautiful forms

With thy brilliance in the Evening-Barque, As when the sacred apes spy thee. ${ }^{37}$

It was said that enneads existed since earliest times. On the Palermo Stone King Sahure is recorded as having made a monument for an ennead in his 6th year:

The king of Upper and Lower Egypt [Sahure; he made it as his monument for]:

The Divine Ennead

$/ / / / / / 38$

When the Egyptian ideas began to be disseminated and known beyond the country's borders, by different cultures and types of mindsets during the long-standing process known as syncretism, they came to be reinterpreted and received rather philosophical connotations. In this way, ennead came to be known by the Pythagoreans who gave it different, related values. Thus according to the Pythagoreans: 


\section{The Works of Plotinus and their Ancient Egyptian Background}

The ennead is the greatest of the numbers within the decade and is an unsurpassable limit. At any rate, it marks the end of the formation of specific identities. . . . That number admits nothing beyond the ennead, but rather everything circles around within it, is clear from the so-called recurrences: there is natural progression up to it, but after it there is repetition. . . . Hence they called it "Oceanus" and "horizon," because it encompasses both of these locations and has them within itself. ${ }^{39}$

\subsection{Plotinus's enneads}

Plotinus' philosophical essays or treatises grew directly out of his teaching. At his death, he left fifty-four such treatises, which were compiled under the title Enneads by Porphyry. The Plotinian treatises, as arranged by Porphyry, represent a movement from the earthly realm to the noetic cosmos and the ineffable One, the supreme God. Thus, the Enneads begin with human goods, proceed to the topics of the physical world, the soul, and the intelligible reality, and finally reach the One, or the Good.

The Greek word ennea means “nine,” and Porphyry arranged the texts as six Enneads, i.e. six sets each containing nine treatises. Plotinus thought of his work as essentially a commentary and exposition of Plato's ideas, and it was thus unwittingly that he gave rise to a new school or movement of Neoplatonism. While he basically accepts Plato's bifurcation of the world into a higher intelligible realm of eternal Forms and a lower sensible world of time and change, what distinguishes his scheme from Plato's is his elaboration of a more refined hierarchy of levels of reality, as well as his explanation of the connection between these various levels. His scheme can be represented as follows: 


\title{
Renata TATOMIR
}

\author{
The One ${ }^{40}$ \\ Embodies: Unity/Truth/Origin/Good \\ Is Source of Essence and Existence
}

Eternal

Act/Utterance

Divine Mind: Presides

Over

Intellectual

Realm

"There"

Act/Utterance

Inner

Soul

All-Soul/World-

Soul/Great Soul

Outer (Nature-Principle) Body

"Here"

World of Matter, Sense,

Time

According to Plotinus, all the various phases of existence emanate from the divinity; the goal of all things is ultimately to return to the divine. Reality is basically bifurcated into an eternal spiritual and intellectual realm (which comprehends the One, the Intellectual Realm, and the All-Soul), and a physical realm of matter, sense, space, and time. Human beings belong to both of these worlds: their souls belong to the higher realm of All-Soul, while their bodies occupy the spatial and temporal world of matter, sense, and extension. The task of philosophy is to facilitate the soul's transcendence of the physical realm, to rise to intellectual intuition and ultimately to attain an ecstatic and mystical union with the One.

In Plotinus' system, the divinity itself is a hierarchical triad expressed in three principles or "hypostases": the One, the Divine Mind or Intellect, and the All-Soul. The One can also be termed the Absolute, the 


\section{The Works of Plotinus and their Ancient Egyptian Background}

Good, or the Father. From this One emanates the Divine Mind, which presides over the realm of Divine Thought or Intellection (this intellectual realm is equivalent to Plato's eternal Ideas or Forms). This Divine Intelligence contains all particular intelligences, and the intellectual forms in this realm are the archetypes of all that exists in the lower, sensible sphere. Moreover, the Divine Intelligence is an expression of the One which is unknowable by mere intellect or reason. From the Divine Mind emanates the All-Soul, or Soul of all things.

The All-Soul has three phases: the intellective soul, which contemplates the Divine Thought of the intellectual realm; the Reasoning Soul, which generates the sensible universe on the model of the archetypes in the intellectual realm; and the Unreasoning Soul, which is the principle of animal life. Hence the All-Soul forms and orders the physical world. It can be seen that each of these phases or levels subsists in two relations, oriented both to that which is higher than itself and to what lies lower. Only the first phase that of the One, is unrelated to any preceding phase, since it is the absolute cause of the others. Unlike Plato, Plotinus does not view these relationships as imitation; rather, each phase is an "emanation" from the preceding phase, retaining the latter's archetypal imprint as a goal to which it must return or conform on its path toward its ultimate reunion with the One. The Soul, then, has an intermediary function, on the one hand gazing back at its own source in the Divine Mind and, on the other, generating all life below it. Plotinus describes the Soul as "the author of all living things, ... whatever is nourished by earth and sea, all the creatures of the air, the divine stars in heaven; it is the maker of the sun; itself formed and ordered this vast heaven and conducts all its rhythmic motion." As such, the Soul is "far more honorable than anything bodily" (Enneads, V.i.2). He explains the connection between this Great Soul or All-Soul and the Divine Mind as follows: "Soul is but an image and un utterance of Divine Mind, the stream of life sent forth by It to the production of further being ... Sprung from Divine Mind, Soul is intellective too; for its perfecting it must look to that Divine Mind which may be thought of as a father watching over his child." On its "upper level," says Plotinus, Soul is united with Divine Mind and "participant in Its nature, but on the lower level in contact with the realm beneath" (Enneads, V.i.3). Hence, Soul is created by an "utterance" of Divine Mind and the two levels are 


\section{Renata TATOMIR}

characterized as in the relation of father and child. Plotinus explains this intermediary function of Soul in another way, in terms of intellect and sense. If we look at the world of sense, he says, at its "vastness and beauty ${ }^{41}$ and . . . order," we can ascend to the Archetype of this world, the more authentic sphere of the intellectual realm, where thoughts are invested with "perfect knowledge."

Presiding over this sphere is the Divine Mind containing "unapproachable wisdom" (Enneads, V.i.4). The Soul, says Plotinus, has an "inner phase, intent upon Divine Mind, and an outer, facing to the external.” By its gazing on the Divine Mind (its inner phase), it retains a likeness to its source; by its external phase, it engages in "action and reproduction . . . so that all its creations bear traces of the Divine Intellection.” In other words, all the creations of the soul are molded - as emanations and images - upon archetypes in the Intellectual sphere (Enneads, V.iii.5).

The realm of Divine Mind, like that of Soul, is eternal. Plotinus describes it as "pure being in eternal actuality; nowhere is there any future, for every then is a now; nor is there any past, for nothing There has ever ceased to be" (Enneads, V.i.4). This intellectual realm is the equivalent of Plato's eternal Forms. Yet Plotinus argues that, since this realm is one of multiplicity, since it contains multiple archetypes and thought essences, it must have its origin in something which is One, something which is an absolute Unity (Enneads, V.i.5). Hence Divine Mind, the intellectual realm, is itself a radiation of the Supreme One: just as Soul is "an act and utterance of Divine Mind," so the Divine Mind "is act and utterance of the One" (Enneads, V.i.6). What, then, is this One to which Plotinus accords absolute sovereignty? Its attributes might be categorized under the headings of unity and presence, truth and goodness. Its most immediate attribute is absolute unity: it is the "All-Transcendent, utterly void of multiplicity," and independent of all else; other entities acquire unity in proportion to their nearness to it. It is the absolute beginning (Enneads, V.iii.15-16). It is the "power from which Life and Intelligence proceed," and it is "the source of essence and existence” (Enneads, V.v.10-11). It cannot be divided, nor is it 


\section{The Works of Plotinus and their Ancient Egyptian Background}

bound to space and time (Enneads, V.i.11). It is infinite, having no definition and no limit; it transcends all being (Enneads, V.v.6). It does not change, and it has no constituent parts, no pattern, and no shape (Enneads, V.v.10-11). What Plotinus says about the "presence" of the One illustrates perhaps more than any other philosophy the significance that Derrida will later attach to this term. The One is "omnipresent; at the same time, It is not present, not being circumscribed by anything; yet, as utterly unattached, not inhibited from presence at any point.” Indeed, the presence of the One is "an instantaneous presence everywhere, nothing containing, nothing left void, everything therefore fully held by Him” (Enneads, V.v.9). Effectively, then, the One is an absolute and immediate presence which contains and comprehends all other presences; He is the archetypal presence in relation to which all other presence (of other entities) is defined.

In terms of knowing and truth, Plotinus states that the "entire Intellectual Order may be figured as a kind of light with the One in repose at its summit as its King . . . But the One, as transcending intellect, transcends knowing. The One is, in truth, beyond all statement” (Enneads, V.iii.12-13). Hence the One stands above all discursive knowledge, beyond the horizons of reason; it can only be grasped partially by those who are "divinely possessed" (Enneads, V.iii.14). Moreover, the object contemplated by the One is not external: "It sees Itself," and in its selfknowing it comprehends all things (Enneads, V.iii.8), being the "King of Truth” (Enneads, V.v.3).

As well as embodying absolute unity, presence, and truth, the One equally embodies absolute goodness. It is the primary goodness toward which the being of all things in ${ }^{42}$ the universe is oriented; things rise above other things in proportion as they possess greater goodness, and in the same proportion they possess more authentic being (Enneads, V.v.9). The One embodies a "Good absolute and unique, the Good . . . unalloyed, alltranscending, Cause of all” (Enneads, V.v.13).

How do human beings apprehend the One? We must, says Plotinus, "put aside the system of sense with desires and impulses" (Enneads, V.iii.9), in order to adjust ourselves for a vision of the One, in a posture of "perfect surrender," enabling us to gleam "in the light of that Presence" 


\section{Renata TATOMIR}

(Enneads, V.v.8). Hence Plotinus’ system is expressed in terms that might lend themselves in a very direct way to later deconstructive strategies: the One is explicitly a "transcendental signified" which authorizes the entire system: it is the absolute origin and goal of human life; it embodies absolute truth and goodness; its presence is not only ubiquitous but allcontaining, preemptively defining all human endeavor and history within the closure of its absolute epistemological and moral authority. This closure is affected by the sharp oppositions between infinite and finite, eternal and temporal, intellect and sense, soul and body. Moreover, each phase in the hierarchy of reality is created by speech, by an utterance. In a real sense, Plotinus' thought might well be viewed as evincing and elaborating characteristics of Plato's vision, unwittingly preparing that vision for its later crucial integration into much Christian theology.

\subsection{Plotinus's ideas on the structure of the universe}

To one who has read Plato, Plotinus' s ideas will be alternately familiar and strange. What is familiar is his metaphysics, the structure of the universe. Like Plato, Plotinus posits an Ideal world (which he calls ekei, "There") as the paradigm for the physical world here below. What is strange is encountering these ideas unaccompanied by the classical clarity of Plato. Like other Neoplatonists, Plotinus derives not only from Plato but also from the Gnostics of Alexandria and the Eastern Mystery cults of Dionysus or Mithras. He gives the impression of an improbable combination of Plato and Zen: This is inaccurate historically, but there is an oriental flavor to his thought.

Plotinus's thought is based on the Higher Ideas, which he views in a complex hierarchy. At the top is The One, the principle of existence itself, Plotinus's God term. ${ }^{43}$ The One gives rise to the Intellectual-Principle, by which things are knowable and differentiable; the Intellectual-Principle is the basis of beauty in the universe. Similarly, the Intellectual-Principle gives rise to the AIl-Soul, which is the paradigm for consciousness here below. In his treatise "On the Intellectual Beauty," Plotinus explains that the Greek gods Ouranos, Kronos, and Zeus are myths of these three Basic 


\section{The Works of Plotinus and their Ancient Egyptian Background}

Ideas, though the Ideas give birth one to the other not through temporal but through logical priority. Below the All-Soul is the Nature-Principle, and it is this that gives rise to matter in all its diverse forms.

Plotinus is not primarily an aesthetician, and when he discusses art, he generally thinks first about painting and sculpture rather than about poetry. Nevertheless, his ideas are a useful adjunct to Plato's because, unlike Plato, Plotinus is basically sympathetic to art. For Plotinus as for Plato, the artist imitates but does not necessarily copy the things of this world. The artist may represent his grasp of an Idea within the medium of his art: "Thus Phidias wrought the [Olympian] Zeus upon no model among things of sense but by apprehending what form Zeus must take if he chose to become manifest to sight." Art at its best can be a way of knowing the Ideas. In fact, it is the artist's grasp of higher things that lends quality to his or her work. This does not mean, however, that the artist should be a mathematician or a philosopher, for art does not derive from reason. Like Benedetto Croce at the beginning of the twentieth century, Plotinus insists that the work of art exists primarily as the intuition of the artist and is known prior to reason. (Plotinus calls it "one totality ... a unity working out into detail ... a distinct image, ... not an aggregate of discursive reasoning and detailed willing.") Beauty exists in its highest degree only there, in lesser degree as the intuition within the soul of the artist, and in still lesser degree ("insofar as it has subdued the resistance of the material") in the concrete and physical work the artist makes. But even natural beauty is primarily a quality of soul: Even beautiful women, Plotinus suggests, are beautiful only insofar as their flesh projects a beautiful spirit. ${ }^{44}$

\subsection{Plotinus' outlook on art and beauty}

These ideas must be understood in the context of his philosophical and theological system as outlined above. Plotinus treats the concept of beauty in two of the Enneads, the sixth treatise of the first Ennead and the eighth section of the Fifth Ennead, entitled "On the Intellectual Beauty." It integrates the nature and function of art, beauty, imitation, and knowledge within a profoundly elaborated philosophical and theological vision.

The first point that Plotinus establishes in this essay is that beauty is ideal: in other words, it belongs essentially to the realm of ideas rather than 


\section{Renata TATOMIR}

to the realm of sensible, physical objects. He gives the example of two stones, one which has been wrought by the artist's hands into a statue, and the other untouched by art. The former, says Plotinus, is beautiful not as stone (i.e. not as matter) but "by virtue of the Form or Idea introduced by the art." And this form exists in the artist's mind before it enters the stone. In the designer's mind, in fact, beauty exists in a far higher form, since it is "concentrated in unity," than it does when it is diffused by entering into matter. Art creates things by an idea it already has of the beautiful object. Plotinus calls this idea the "Reason-Principle" (Enneads, V.viii.1). And this idea is more beautiful in its pure form than when it is mingled with matter. Indeed, it is only as an idea that beauty can enter the mind. Hence, beauty is not in the concrete object but in "soul or mind" (Enneads, V.viii.2).

Plotinus now explains the origin of beauty, with reference to his cosmological hierarchy. Nature, he says, which creates beautiful things must itself be produced by a 45 "far earlier beauty." The "Nature-Principle" (which lies below the level of the All-Soul) contains "an Ideal archetype of the beauty that is found in material forms." But this archetype itself has its source in a still more beautiful archetype in Soul. And this archetype, in turn, has its source in the Intellectual-Principle, in the realm of pure intellectual Forms. Plotinus' term for this intellectual realm is "There." He designates the sensible world as "Here" (Enneads, V.viii.3). Plotinus sees the realm of "There" as inhabited by "gods," a term he uses somewhat metaphorically to designate the divine order or certain exalted beings who minister to the supreme God. ${ }^{46}$ These "gods" or inhabitants of the intellectual realm are beautiful not on account of their corporeal forms but by virtue of their intellect. In that realm, which is a realm of authentic, eternal being and not of process and becoming, everything is clear and transparent: "every being is lucid to every other . . . And each of them contains all within itself, and at the same time sees all in every other, so that everywhere there is all . . . While some one manner of being is dominant in each, all are mirrored in every other." And all the beings of that world are engaged in "contemplation of an infinite self" (Enneads, V.viii.4). 


\section{The Works of Plotinus and their Ancient Egyptian Background}

Plotinus sees the many gods of the divine realm as being "distinct in powers but all one god in virtue of that one divine power of many facets . . . this is the one God who is all the gods" (Enneads, V.viii.9). The wisdom of that realm is "not a wisdom built up by reasonings but complete from the beginning, . . . a wisdom primal, unborrowed, not something added to the Being, but its very essence" (Enneads, V.viii.4). Hence, the world of "There" or the intellectual realm is a world of complete unity, where all the beings merge into an infinite divine identity. Moreover, the system of wisdom is also a unity, complete, self-enclosed, and acting as the measure of all subsequent wisdom.

Plotinus suggests that knowledge or wisdom is not something extraneous to existence; it is part of the very essence of being. He goes so far as to define reality as wisdom: "Being is Real by virtue of its origin in wisdom." Knowledge in that realm, then, is not discursive; it is not expressed in language; it exists "There not as inscription but as authentic existence.” Like Plato, he regards the Ideas or Forms as actual existents or beings (Enneads, V.viii.5). Like the ancient Egyptian hieroglyphs, each manifestation of knowledge and wisdom in the intellectual realm "is a distinct image, an object in itself, an immediate unity, not an aggregate of discursive reasoning." Plotinus calls this "wisdom in unity" (Enneads, V.viii.6).

In the world of "Here," the sensible world, things are very different. Everything is "partial," including our knowledge, which exists as "a mass of theorems and an accumulation of propositions" (Enneads, V.viii.4). The kind of wisdom we possess is only an image of the original "wisdom in unity," an image that reproduces the original in a discursive form, in language, using reasoning (Enneads, V.viii.6). The one exception to this limitation lies in art: the artist goes back to "that wisdom in Nature which is embodied in himself; and this is not a wisdom built up of theorems but one totality, not a wisdom consisting of manifold detail co-ordinated into a unity but rather a unity working out into detail" (Enneads, V.viii.5). Hence the artist, according to Plotinus, seems to have a more direct intuitive access into that earlier wisdom than does the philosopher or the scientist. His vision begins as an immediate unity that extends to comprehend greater 


\section{Renata TATOMIR}

and greater detail whereas the philosopher's knowledge is cumulative, starting with details or parts and then arriving at a totality. ${ }^{47}$

Indeed, according to Plotinus, the entire universe was created in this "artistic" fashion: it could not have been thought out in detail and built up step by step. Rather, its existence and nature "come to it from beyond itself . . . all things must exist in something else." In other words, the entire universe is a copy or image of a preexisting world: "the entire aggregate of existence springs from the divine world, in greater beauty" (Enneads, V.viii.7). The beauty of the divine world is greater because it exists in a pure form, unmingled with matter.

According to this account of creation, everything that could possibly exist in our sensible world already existed as an archetype in the realm of Forms: "From the beginning to end," says Plotinus, "all is gripped by the Forms of the Intellectual Realm” (Enneads, V.viii.7). Even matter is an Idea, though it is the lowest of the ideas. Hence, the universe in its entirety is essentially ideal: its reality consists not in its material aspects but in the archetypal ideas underlying all its material forms, and the crucial elements in its creation were "Being and Idea" (Enneads, V.viii.7).

Earthly beauty, therefore, derives from the perfect beauty of the divine world. This conception of beauty is at first difficult for one to grasp since in our world one is accustomed to perceive beauty through one's senses. In Plotinus' system, beauty is perceived not at all by the senses but by the intellect and this is one of the bases of his divergence from Plato's views of art and poetry. He actually cites an observation from Plato's Timaeus that the Creator approves his work, once he has created the universe. For Plotinus, beauty plays an important role in drawing human souls toward the truth of the higher realm. The Creator's intention, he says, was "to make us feel the lovable beauty of the archetype and of the Divine Idea” (Enneads, V.viii.8).

Thus, whereas Plato sees poetry as appealing to man's lower nature, his desires and passions, Plotinus sees in art a means of access to the divine world, based on art's reproduction of the beauty of that world, a beauty 


\section{The Works of Plotinus and their Ancient Egyptian Background}

discernible not to the senses and passions but to the intellect. A further crucial way in which Plotinus diverges from Plato is his insistence on a logic of continuity between the two realms, intellectual and sensible: Plato's denigration of the sensible world does not make sense, according to Plotinus, since this world derives from and is modeled after the archetypes of the higher realm. Where Plato equates "imitation" with ontological and epistemological inferiority, Plotinus stresses the continuity with an original that imitation embodies: "to admire a representation," he urges, "is to admire the original upon which it was made." Moreover, there is no intrinsic defect in the sensible world, which is itself beautiful: "if the divine did not exist, the transcendently beautiful, in a beauty beyond all thought, what could be lovelier than the things we see? Certainly, no reproach can rightly be brought against this world save only that it is not That" (Enneads, V.viii.8). Hence, the sensible world appears defective only in comparison with the intellectual; but, by the same token, it perpetuates and expresses the beauty of that higher world according to its own capacity and appropriate position in that hierarchy. Plotinus says that this "second Cosmos [i.e., our human world] at every point copies the archetype: it has life and being in copy ... In its character of image it holds, too, that divine perpetuity" (Enneads, V.viii.12). These statements are crucial: "life and being in copy": Plotinus ascribes an independent function and value to imitation, to copy, to image. Where Plato treated the images offered by art as merely adjectival upon their originals, Plotinus sees the ${ }^{48}$ image itself as valuable, as a further level of reality that perpetuates the divine ideas or originals whose trace it bears.

Plato would see a painting of a horse merely as a relation, a relation to an actual horse. Plotinus sees a value and function in the painting itself, in the image, which may in some respects be superior to the natural object. As Plotinus states, Plato "fails to see that as long as the Supreme is radiant there can be no failing of its sequel" (Enneads, V.viii.12). Hence, image and copy are modes of exalting and continuing the divine ideas, rather than imperfect betrayals and distortions of them. Moreover, in opposition to Plato's notion of art as an imitation of nature, which is itself an imitation of the eternal Forms, Plotinus holds that art does not engage in a bare reproduction of things in nature but goes "back to the Reason-Principles 


\section{Renata TATOMIR}

from which Nature itself derives . . . they are holders of beauty and add where nature is lacking” (Enneads, V.viii.1).

Hence, where Plato thought of art as imitating what was already an imitation (of eternal Forms), Plotinus sees art as directly imitating the Forms themselves, and with a directness inaccessible to the discursive reasoning of philosophy. Plotinus accords priority to the notion of beauty in yet another way. Just as he defines wisdom as part of the essence of being, so he includes beauty within that essence: "Beauty without Being could not be, nor Being voided of Beauty: abandoned of Beauty, Being loses something of its essence. Being is desirable because it is identical with Beauty" (Enneads, V.viii.9). Hence beauty, like wisdom, is not an attribute that is externally added to existence: things have being only to the extent that they possess beauty and wisdom. For Plotinus, "the final object of all seeing," or the ultimate purpose of our contemplation, is "the entire beauty upon all things" (Enneads, V.viii.10). Again, "beauty" here is a far richer term than it is in our world: discerned by the intellect, it comprehends the order, proportion, and perfection of the world on a number of levels, including those of knowledge and goodness, which might be said to harbor aesthetic dimensions.

Plotinus ends his treatise with what is perhaps one of the most beautiful and insightful passages ever composed by a philosopher. The perception of beauty is not a passive act, of gazing upon a beautiful object that is external to the spectator. If our vision of beauty is merely partial and sensual, says Plotinus, "the immediate impression is alone taken into account" and we remain passive observers. However, if our souls are "penetrated by this beauty," we cannot remain mere gazers, mere spectators: "one must bring the vision within and see no longer in that mode of separation but as we know ourselves" (Enneads, V.viii.10). For example, if we seek a vision of God, we must find that vision within ourselves. Plotinus offers an account of mystical union with God, an account that shares much with, and indeed influenced, subsequent Christian and Islamic forms of mysticism. If we submit ourselves to the vision of God, we will lose our own self, and be unable to see our own image; 


\section{The Works of Plotinus and their Ancient Egyptian Background}

possessed by God, we will see our own image "lifted to a better beauty"; progressing further, we will "sink into a perfect self-identity," forming "a multiple unity with the God silently present” (Enneads, V.viii.11).

Hence the first stage of this ascent to union with God is separation, a state in which we ${ }^{49}$ are aware of self; but if we turn away from sense and desire, we become "one in the Divine": instead of remaining in the mode of separation, of mere spectator or seer, we ourselves become "the seen," the object of our own vision or self-knowledge. Hence, truly to know beauty is to become it: we must put behind us reliance on sense or sight, which "deals with the external." There can be no vision of beauty, says Plotinus, "unless in the sense of identification with the object... And this identification amounts to a self-knowing, a self-consciousness." We are "most completely aware of ourselves when we are most completely identified with the object of our knowledge" (Enneads, V.viii.11). In these passages, Plotinus anticipates not only numerous forms of mysticism, both Eastern and Western, but also the philosophies of such thinkers as Kant and Hegel who regard all consciousness as self-consciousness. For Plotinus, knowledge - of beauty or anything else - is a form of interaction, a mode of unity rather than separation, a manner of internalizing the object and being transformed by it, a process of mutual adaptation of self and object, losing the one in the other, in a merged identity.

Plotinus equates the Greek gods Uranus, Cronus, and Zeus respectively with the One, the Intellectual-Principle, and the All-Soul. Cronus, in this mythological explanation, holds a mid-position, standing between "a greater Father" (Uranus) and "an inferior son" (Zeus). Interesting here is Plotinus' observation that the "father" or the One "is too lofty to be thought of under the name of Beauty," hence it is the "second God" or Cronus who "remains the primally beautiful" (Enneads, V.viii.13). In other words, the primordial beauty belongs in Plotinus' system not to the One but to the intellectual realm. Plotinus says that we "ourselves possess beauty when we are true to our own being . . . our self-knowledge ... is our beauty" (Enneads, V.viii.13). Truth to our own being would reside in acknowledging our purpose to return to the divine, to unity with the absolute Unity, and in laying aside the multifold temptations of the world of sense. This helps further explain Plotinus' view of knowledge as 


\section{Renata TATOMIR}

identification with our object: we know ourselves through the object, the latter being the form of our self-knowledge, and in such self-knowing we do not merely perceive beauty externally but become it, making it our very being. Where Plato distanced art and poetry from knowledge, Plotinus sees an internal connection between knowledge and beauty as predicates of being, whereby each of these shapes the other; hence beauty acquires a heightened importance which in turn underlies the significance of art.

In the essay called "Beauty" in the First Ennead, which exerted considerable influence on artists during the Renaissance, Plotinus approaches the concept of beauty in similar terms but from a slightly different perspective, that of the soul which seeks to apprehend true beauty. He acknowledges that, in our ordinary lives, beauty addresses itself chiefly to the senses, to sight and hearing; there is also a beauty, he says, in the noble conduct of life and the pursuits of the intellect, and in "all that derives from the Soul" (Enneads, I.vi.1). He affirms that there is a single principle underlying these various forms of beauty, a principle remembered by the soul from its previous, unbodily, existence. "The soul," he says, "includes a faculty peculiarly addressed to Beauty," a faculty that enables it to recognize beauty with certainty in the light of the soul's own earlier affiliation with the highest being (Enneads, I.vi.2). As in the other treatise, Plotinus maintains that all earthly beauty derives from the ideal Forms. But what is interesting is his additional explanation of beauty as the formation of unity from multiplicity, a view that was deeply influential in the Middle Age. All shapelessness of ${ }^{50}$ matter, he suggests, that has not been patterned and structured by the ideal Forms on the basis of reason is ugly in virtue of its "isolation from the Divine Thought." But where the ideal Form has operated, it has grouped and coordinated "a diversity of parts” into a unity: "it has rallied confusion into co-operation; it has made the sum one harmonious coherence; for the Idea is a unity and what it moulds must come to unity as far as multiplicity may." And it is on this unity that "Beauty enthrones itself” (Enneads, I.vi.2).

Thus, not only is beauty intrinsically affiliated to order and unity but also unity itself is a characteristic of the divine, of the highest realm of 


\section{The Works of Plotinus and their Ancient Egyptian Background}

the hierarchy; the lower one descends in that hierarchy, the more existence or being spans out into multiplicity. Therefore, for Plotinus the ascent to God, to goodness, truth, and beauty, was effectively an escape from the bondage of worldly multiplicity and a return to the unity whence one came. Hence the "principle" underlying all beauty is a principle "whose labor is to dominate matter and bring pattern into being" (Enneads, I.vi.3). It is a principle of both order and unity.

The rest of Plotinus' essay describes the means whereby the soul can rise to the perception of true beauty. He reminds us that there are "earlier and loftier beauties" than those perceived in the world of sense, but only the "soul sees and proclaims them." Indeed, only the soul can apprehend the beauty of noble conduct, virtue, and learning (Enneads, I.vi.4). But for the soul to attain a vision of the highest beauty, it must renounce the body, all material pursuits and desires, and live within its "veritable self." To attain to its authentic self, it must remove all "internal discord" and dissolve its "alien nature" as formed by commerce with the material world (Enneads, I.vi.5).

The soul on this upward path is obliged to "renounce kingdoms and command over earth and ocean and sky" (Enneads, I.vi.7). When the soul is thus cleansed, it is comprised of "all Idea and Reason . . . Intellection and all that proceeds from Intellection are the soul's beauty." Indeed, in becoming a good and beautiful thing, the soul becomes like God, "for from the Divine comes all its beauty and the rest of its share in Existence. We may even say that Beauty is the Authentic Existence” (Enneads, I.vi.6). As in the other essay, Plotinus equates beauty with real being and explains that the soul derives its beauty from the Divine Mind; in turn, the soul is "the author of the beauty found in the world of sense" (Enneads, I.vi.6).

To ascend to the beauty whence it came, the soul must withdraw inward, into itself, foregoing the mode of earthly sensual vision, and recognizing that earthly beauties are "copies, vestiges, shadows." The soul's journey, says Plotinus, is to the fatherland: "The Fatherland is There whence we have come, and There is the Father" (Enneads, I.vi.8). To undertake this journey, the soul must waken in itself its own power of vision, perfecting itself until it achieves an "inner unity," true to its "essential nature." At this point, says Plotinus, "you are now become very 


\section{Renata TATOMIR}

vision.” In other words, the entire soul has become nothing but vision, losing itself in what it seeks, and acquiring its authentic self in God. Just as in the other treatise Plotinus urged that subject and object, knower, and known, should become one, so here he suggests that the soul must itself become of the same nature as the object of its vision: "never did eye see the sun unless it had first become sunlike, and never can the soul have vision of the First Beauty unless itself be beautiful” (Enneads, I.vi.9). And the final object of vision, which may equally be called beauty, goodness, or truth, is, of course, God, the journey to whom must be conducted ${ }^{51}$ in isolation from all else: "each in the solitude of himself shall behold that solitary [...] Existence, the Apart, the Unmingled, the Pure, That from which all things depend, towards Which all look, the Source of Life, of Intellection and of Being” (Enneads, I.vi.7).

\section{Conclusions}

It can be concluded that in Plotinus' system, God circumscribes the entire journey of human life at every level: as beginning and end, as identity of truth, goodness, and beauty, and as the very constitution of being or existence by these three predicates. This conception of beauty, far removed from ours, was an integral part of the order and unity of the universe, and of the relation of finite creatures to the Divine. It is obvious that Plotinus' rehabilitation of poetry and the arts is enabled by his intricate reformulation of both Plato's metaphysics and his aesthetics.

\section{Bibliography}

Atkins, J. W. H. 1934, Literary Criticism in Antiquity: A Sketch of its Development, Cambridge, 1934.

Breasted, J. H. 1906-1907, Ancient Records of Egypt, Historical Documents from the Earliest Times to the Persian Conquest, Vols. I, III, Chicago: University of Chicago Press. 


\section{The Works of Plotinus and their Ancient Egyptian Background}

The Cambridge History of Literary Criticism - CHLC 1990, Edited by George Alexander Kennedy, University of South Carolina, Cambridge University Press, V.I.

Copleston, F. C. 1977, Aquinas, Harmondsworth, Penguin.

Day, G. 2008, Literary Critcism: A New Hitory, Edinburgh, Edinburgh University.

Dillon, J. 1996, The Middle Platonists: A Study of Platonism 80 B.C. to A.D. 220, revised edition with new afterword, London, Duckworth, pp. 383 and 381.

Ford, A. 2002, The Origins of Criticism, Princeton.

Glucker, J. 1978, Antiochus and the Late Academy, Gottingen, Vanderhoeck and Ruprecht.

Habib, M.A.R. 2005, Modern Literary Criticism and Theory. A History of Literary Critcism. From Plato to the Present, Blackwell Publishing.

Laird, A. (Editor) 2006, “The Value of Ancient Literary Criticism”, in Oxford Readings in Classical Studies. Ancient Literary Criticism, Oxford, Oxford University Press, pp. 1- 16.

Minnis, A. J., and A. B. Scott (Eds) 2000, Medieval Literary Theory and Criticism c. 1100-c. 1375: The Commentary Tradition, Oxford, Clarendon Press.

Murray, Penelope, and T. S. Dorch 2000, Classical Literary Criticism, Harmondsworth, Penguin, p. 107.

Preminger, Alex, O. B Hardison Jr. and Kevin Kerrane (Eds) 1974, Classical and Medieval Literary Criticism: Translations and Interpretations, New York, Frederic Ungar.

Richter, D. H. (Editor) 2007, The Critical Tradition. Classic Texts and Contemporary Trends, Third Edition, Bedford/St Martin's, Boston New York.

"The Philosophy of Plotinus the Egyptian" (Excerpts), in Uždavinys, A. (Editor), The Heart of Plotinus: The Essential Enneads 2009, World Wisdom, INC., Foreword by Jay Bregman, World Wisdom online library, pp. 1-14, www.worldwisdom.com/public/library/default.aspx, http://www.worldwisdom.com/public/viewpdf/default.aspx?articletitle=Selections_from_The_Philosophy_of_Plotinus_the_Egyptian.pdf 


\section{Renata TATOMIR}

Turnbull, Grace H. (Editor) 1948, The Essence of Plotinus: Extracts from the Six Enneads and Porphyry's Life of Plotinus, trans. Stephen Mackenna, New York and Oxford, Oxford University Press.

Wimsatt, William K., and Cleanth Brooks 1957, Literary Criticism: A Short History, London, Routledge \& Kegan Paul, Wimsatt and Brooks.

Notes:

1 Laird, A. (Editor) 2006, “The Value of Ancient Literary Criticism”, in Oxford Readings in Classical Studies. Ancient Literary Criticism, Oxford, Oxford University Press, pp. 1- 16, pp. 1 seq.

${ }^{2}$ Ibidem.

3 Atkins, J. W. H. 1934, Literary Criticism in Antiquity: A Sketch of its Development, Cambridge, 1934, i. 1.

${ }^{4}$ Ibidem, pp. 2-3.

5 To Ford (2002, p. 3) "praise” and “blame” , ‘are the Greeks' own general terms for what one says in response to song; they remind us that interpretation need not be the primary function of criticism and helpfully separate the history of criticism from the history of aesthetic response. What people felt as opposed to what they said about poetry is not only inaccessible to the historian but should not be accorded a priori the same importance it may have in modern, privatized notions of aesthetic experience.' Apud Laird 2006, Ibidem.

${ }^{6}$ Ibidem.

${ }^{7}$ Habib, M.A.R. 2005, Modern Literary Criticism and Theory. A History of Literary Criticism. From Plato to the Present, Blackwell Publishing, pp. 129 sq.

${ }^{8}$ CHLC 1990, V.I, 298.

${ }^{9}$ Ibidem.

${ }^{10}$ Ibidem, pp. 129-130.

${ }^{11}$ Ibidem, p. 130.

12 Ibidem, p. 130 apud “Introduction,” in Turnbull, Grace H. (Editor) 1948, The Essence of Plotinus: Extracts from the Six Enneads and Porphyry's 


\section{The Works of Plotinus and their Ancient Egyptian Background}

Life of Plotinus, trans. Stephen Mackenna, New York and Oxford, Oxford University Press, pp. xvi-xix. Hereafter cited as Enneads.

13 Day, G. 2008, Literary Criticism: A New History, Edinburgh, Edinburgh University Press, p. 74.

14 Preminger, Alex, O. B Hardison Jr. and Kevin Kerrane (Eds) 1974, Classical and Medieval Literary Criticism: Translations and Interpretations, New York, Frederic Ungar, p. 232.

15 Ibidem.

${ }^{16}$ Ibidem, p. 229.

17 Ibidem, p. 228.

18 Ibidem, p. 232.

${ }^{19}$ Ibidem, p. 231.

${ }^{20}$ Murray, Penelope, and T. S. Dorch 2000, Classical Literary Criticism, Harmondsworth, Penguin, p. 107.

${ }^{21}$ For a good introduction to Aquinas, see Copleston, F. C. 1977, Aquinas, Harmondsworth, Penguin, and for a brief introduction to his life and works, see Aquinas, <http://www.utm.edu/research/iep/a/aquinas.htm>

${ }^{22}$ Because of his portly figure Thomas Aqunas was nicknamed 'the dumb ox'.

${ }^{23}$ Wimsatt, William K., and Cleanth Brooks 1957, Literary Criticism: A Short History, London, Routledge \& Kegan Paul, Wimsatt and Brooks p. 129.

24 Day 2008, p. 74 apud Minnis, A. J., and A. B. Scott (Eds) 2000, Medieval Literary Theory and Criticism c. 1100-c. 1375: The Commentary Tradition, Oxford, Clarendon Press, pp. 26 and 28.

${ }^{25}$ Ibidem.

${ }^{26}$ Richter, D. H. (Editor) 2007, The Critical Tradition. Classic Texts and Contemporary Trends, Third Edition, Bedford/St Martin's, Boston New York, pp. 109-110.

27 “The Philosophy of Plotinus the Egyptian” (Excerpts), in Uždavinys, A. (Editor), The Heart of Plotinus: The Essential Enneads 2009, World Wisdom, INC., Foreword by Jay Bregman, World Wisdom online library, pp. 1-14, www.worldwisdom.com/public/library/default.aspx, http://www.worldwisdom.com/public/viewpdf/default.aspx?articletitle=Selections_from_The_Philosophy_of_Plotinus_the_Egyptian.pdf, p. 4. 


\section{Renata TATOMIR}

${ }^{28}$ Ibidem, pp. 4-5.

${ }^{29}$ Ibidem, p. 5.

${ }^{30}$ Dillon, J. 1996, The Middle Platonists: A Study of Platonism 80 B.C. to A.D. 220, revised edition with new afterword, London, Duckworth, pp. 383 and 381.

${ }^{31}$ Ibidem, p. 383.

${ }^{32}$ Armstrong, A.H. 1967, The Architecture of the Intelligible Universe in the Philosophy of Plotinus, Amsterdam, Adolf M. Hakkert, pp. 7 and 57.

33 "The Philosophy of Plotinus the Egyptian" (Excerpts), in Uždavinys, A. (Editor), The Heart of Plotinus: The Essential Enneads 2009, World Wisdom, INC., Foreword by Jay Bregman, World Wisdom online library, pp. 1-14, www.worldwisdom.com/public/library/default.aspx, http://www.worldwisdom.com/public/viewpdf/default.aspx?articletitle=Selections_from_The_Philosophy_of_Plotinus_the_Egyptian.pdf, p. 5.

${ }^{34}$ Dillon, 1996, p. 383.

35 Glucker, J. 1978, Antiochus and the Late Academy, Gottingen, Vanderhoeck and Ruprecht, p. 313.

36 Breasted, J. H. 1906-1907, Ancient Records of Egypt, Historical Documents from the Earliest Times to the Persian Conquest, Vols. I, 3, Chicago: University of Chicago Press, Part One, § 500.

37 Tomb of Horemheb, Breasted, ibidem, Part Three, $\S 16$.

${ }^{38}$ Breasted, ibidem, Part One, § 160.

39 The Theology of Arithmetic: On the Mystical, Mathematical, and Cosmological Symbolism of the First Ten Numbers. Attributed to Iamblichus, trans. Robin Waterfield, Grand Rapids, Phanes Press, 1988, p. 105. Apud “The Philosophy of Plotinus the Egyptian” (Excerpts), in Uždavinys, A. (Editor) 2009, The Heart of Plotinus: The Essential Enneads, World Wisdom, INC., Foreword by Jay Bregman, World Wisdom online library, pp. 1-14, www.worldwisdom.com/public/library/default.aspx, http://www.worldwisdom.com/public/viewpdf/default.aspx?article- 


\section{The Works of Plotinus and their Ancient Egyptian Background}

title=Selections_from_The_Philosophy_of_Plotinus_the_Egyptian.pdf, pp.11 seq.

${ }^{40}$ Habib 2005, p. 130.

${ }^{41}$ Ibidem, p. 131.

${ }^{42}$ Ibidem, p. 132.

${ }^{43}$ Ibidem.

${ }^{44}$ Ibidem.

${ }^{45}$ Ibidem, p. 133.

${ }^{46}$ This terminology is admirably explained by Grace Turnbull in Enneads, pp. 15-16.

47 Ibidem, p. 134.

${ }^{48}$ Ibidem, p. 135.

${ }^{49}$ Ibidem, p. 136.

${ }^{50}$ Ibidem, p. 137.

${ }^{51}$ Ibidem, p. 138. 